\title{
Chronic Cadmium Poisoning Induced by Environmental Cadmium Pollution. Renal Lesions (Multiple Proximal Tubular Dysfunctions) Identified in Residents of Cadmium-Polluted Hosogoe, Kosaka Town, Akita Prefecture, Japan
}

\author{
Hiroshi Saito, M D, Ryuji Shioji, M D, Yotaro Hurukawa, M D, Takashi Arikawa, M D, \\ Takao Saito, M D, Ken-ichi NagaI, M D, Takashi Furuyama, M D \\ and Kaoru Yoshinaga, M D
}

The Second Department of Internal Medicine, Tohoku University School of Medicine, Sendai

\begin{abstract}
Health examinations were performed in 137 people living in the cadmium-polluted community of Hosogoe, Kosaka town, Akita prefecture, Japan. Thirty-three of 137 residents had some indications of proximal tubular dysfunctions such as renal glycosuria, tubular proteinuria and generalized aminoaciduria, and 10 of them were diagnosed as having multiple proximal tubular dysfunctions. Detailed examinations revealed that none of these cases had any causal diseases other than chronic cadmium poisoning. The ages of the 33 cases ranged from 36 to 83 years, and all have lived in Hosogoe area for more than 28 years. The community of Hosogoe, with a leading Japanese copper refinery in operation since the $1870 \mathrm{~s}$, is surrounded with the farmland evidently polluted by cadmium primarily through the air. The mean concentration of cadmium in unpolished rice harvested in this area was found some ten times as high as that in the control area. The residents' mean cadmium intake and mean urinary cadmium concentration showed the values over 3 times as high as those in control. It is quite conceivable that the people of Hosogoe have had a high daily intake of cadmium for many years mainly via food. From these findings, renal lesions identified in the residents were diagnosed as chronic cadmium poisoning induced by the environmental cadmium pollution.
\end{abstract}

Key Words: Chronic cadmium poisoning, Environmental cadmium pollution, Proximal tubular dysfunctions, Fanconi syndrome, Tubular proteinuria, Urine proteins, Retinol-binding protein, Uric acid clearance, Generalized aminoaciduria, Renal tubular disorders

Since the so-called "Itai-Itai disease" found in residents of the Jinzu river basin

Received for publication June 2, 1976.

Reprint requests to: Hiroshi Saito, The Second

Department of Internal Medicine, Tohoku University School of Medicine, 1-1, Seiryocho, Sendai Gity, Japan. in the 1950s was believed to have a close relation to the environmental cadmium pollution, and there were found many other places polluted by cadmium, the cadmium effect on health has become a serious and social problem in Japan ${ }^{1-2)}$.

We have conducted health examinations 
on the people of Hosogoe, Kosaka town, Akita prefecture, an area seriously polluted by cadmium, and found that many people were suffering from renal lesions induced by environmental cadmium pollution. This is the first report of detailed renal function tests on the people in a cadmium-polluted area.

\section{MATERIALS AND METHODS}

1) The Hosogoe area of Kosaka town is adjacent to a leading Japanese copper refinery that initiated operation in the 1870 s. The soil of the area had been so significantly polluted by cadmium from industrial smokestacks that high concentrations of cadmium were detected at random survey in area's soil, rice and vegetables.

In 77 samples of unpolished rice produced in the area from 1970 to 1975 , the mean concentration of cadmium (mean \pm S.D.) was $0.66 \pm 0.72 \mu \mathrm{g} / \mathrm{g}$ wet weight, some ten times as high as the corresponding level for the counterparts in non-polluted areas.

2) Urine tests;

Qualitative analysis of morning urine was made by applying the $20 \%$ sulfosalicylic acid test and Testape test to determine proteinuria and glycosuria. Indications over +1 were accepted proteinuria and over weak positive for glycosuria. Cases with concurrent proteinuria and glycosuria were subjected to polyacrylamide gel zone electrophoresis for concentrated urine proteins ${ }^{3}$, counter immunoelectrophoresis for urinary retinol-binding protein ${ }^{4}$, and thin-layer chromatography for urinary aminoacids ${ }^{5}$.

3) Renal function tests;

Renal plasma flow was determined by PAH-clearance, glomerular filtration rate by 24 -hour endogeneous creatinine clearance $^{6)}$, phosphate clearance by FiskeSubbarow's method ${ }^{7)}$, and uric acid clearance by the uricase method ${ }^{8}$. For the determination of $\mathrm{HCO}_{3}^{-}$-threshold and of acidifying ability of urine were used oral bicarbonate loading test and ammonium chloride loading test, respectively ${ }^{9,10)}$

4) Diagnostic criteria for multiple proximal tubular dysfunctions:
In this study we applied the diagnostic term of "multiple proximal tubular dysfunctions" to cases fulfilling either of the following two:

1. Fanconi syndrome (Phospho-glucoaminoaciduria)

2. Showing more than 4 of the following 6 indications, necessarily including renal glycosuria or generalized aminoaciduria,

Renal glycosuria, Generalized aminoaciduria, Decreased \% TRP, High value of uric acid clearance, Decreased $\mathrm{HCO}_{3}^{-}$-threshold, Tubular proteinuria.

\section{RESULTS}

1) Quantitative analyses for proteinuria and glycosuria (Table 1):

The results of urine tests performed in 137 residents (96\% of the target population) are shown in Table 1.

Concurrent proteinuria and glycosuria was found on each occasion in $13-22 \%$ of them. In the four-time tests, concurrent proteinuria and glycosuria was identified in 33 (18 males and 15 females) of the 137 persons (59 males and 78 females). They included 14 people in 7 families, comprising 2 house-holds of husbands and wives, 2 of parents and children-in-law, and 3 of blood parents and children, in other words, 3 families of blood ties and 4 of no blood ties.

Control was used in 40 persons of over 35 years of age living in the non-polluted community of Iwasawa, Kosaka town. Urine test confirmed concurrent proteinuria and glucosyria in only one $(2.5 \%)$ of the 40 subjects. This patient was one long suffering from diabetes mellitus.

2) Polyacrylamide gel zone electrophoresis (Table 2, 6):

Concentrated urine proteins were analysed in 19 of the 33 cases with concurrent proteinuria and glycosuria. Tubular proteinuria was found in 10 cases, including 9 (Case 1-6, 14, 16 and 17) diagnosed as having multiple proximal tubular dysfunctions. The remaining one case (Case 7) had also 
Table 1. Precalenve of proteinuria and glycosuria among the Hosogoe residents of over 35 years of age.

\begin{tabular}{|c|c|c|c|c|}
\hline \multicolumn{2}{|c|}{$\begin{array}{c}\text { Number of } \\
\text { persons examined }\end{array}$} & $\begin{array}{l}\text { Proteinuria } \\
\text { number }(\%)\end{array}$ & \multirow[t]{2}{*}{$\begin{array}{l}\text { Glycosuria } \\
\text { number (\%) }\end{array}$} & \multirow[t]{2}{*}{$\begin{array}{c}\text { Concurrent proteinuria } \\
\text { and glycosuria } \\
\text { number ( } \%)\end{array}$} \\
\hline January 1972 & & & & \\
\hline Male & 24 & $5(21)$ & $3(13)$ & $3(13)$ \\
\hline Female & 51 & $9(18)$ & $7(14)$ & $7(14)$ \\
\hline Total & 75 & $14(19)$ & $10(13)$ & $10(13)$ \\
\hline \multicolumn{5}{|l|}{ October 1972} \\
\hline Male & 40 & $13(33)$ & $9(23)$ & $5(13)$ \\
\hline Femare & 56 & $22(38)$ & $9(16)$ & $8(14)$ \\
\hline Total & 96 & $35(36)$ & $18(19)$ & $13(14)$ \\
\hline \multicolumn{5}{|l|}{ October 1973} \\
\hline Miale & 37 & $16(43)$ & $14(38)$ & $7(19)$ \\
\hline Female & 48 & $16(33)$ & $6(13)$ & $4(8)$ \\
\hline Tota1 & 85 & $32(38)$ & $20(24)$ & (13) \\
\hline \multicolumn{5}{|l|}{ October 1974} \\
\hline Male & 41 & $16(39)$ & $12(29)$ & $12(29)$ \\
\hline Female & 46 & $21(46)$ & $7(15)$ & $7(15)$ \\
\hline Total & 87 & $37(43)$ & $19(22)$ & $19(22)$ \\
\hline
\end{tabular}

Target population. 1972: Male 54, Female 63, Total 117 persons.

1973. Male 54, Female 62, Total 116 persons.

1974. Male 53, Female 61, Total 114 persons.

Total taget population from 1972 to 1974 was 142 persons.

Total number of persons examined from 1972 to 1974 was 137 persons.

some indications of proximal tubular malfunctions such as renal glycosuria and a high value of uric acid clearance.

3) Analysis of urinary aminoacids(Table $2,6)$ :

Urinary aminoacids were analysed in 25 of the 33 cases with concurrent proteinuria and glycosuria. Generalized aminoaciduria was identified in 7 of them. Increased excretion of urinary aminoacids was found in 3, while the other 15 cases were normal.

All 7 cases with generalized aminoaciduria and 2 of the 3 cases with increased excretion of aminoacids were diagnosed as having multiple proximal tubular dysfunctions, while this diagnosis was established in only one case (Case 6) of the 15 normal persons.

4) Urinary retinol-binding protein (Table 2, 6);
Urinary retinol-binding protein was measured by the method of counter immunoelectrophoresis in all 37 cases showing proteinuria and in random 23 cases without proteinuria, totaling 60 cases, in October 1974 (Table 1). Those showing a retinol-binding protein concentration of over $0.4 \mathrm{mg} / \mathrm{dl}$ were determined as positive cases.

Of the 60 cases, 8 were positive. All these 8 were positive cases of proteinuria, including 6 with multiple proximal tubular dysfunctions. One of the other 2 was Case 7 mentioned above. The remaining one was not examined.

Only one (Case 3 ) of 52 cases with negative retinol-binding protein was a case of multiple proximal tubular dysfunctions.

As shown in Table 2 and 6 , the above three methods were all proved to be highly reliable screening tests for multiple proximal 
Table 2. Laboratory findings on 13 hospitalized cases with concurrent proteinuria and glycosuria (I).

\begin{tabular}{|c|c|c|c|c|c|c|c|c|c|c|c|c|c|c|c|}
\hline \multirow[t]{3}{*}{ Case } & \multirow[t]{3}{*}{ Sex } & \multirow[t]{3}{*}{ Age } & \multirow{3}{*}{$\begin{array}{l}\text { Years of } \\
\text { residence }\end{array}$} & \multicolumn{7}{|c|}{ Urine } & \multicolumn{5}{|c|}{ Plasma } \\
\hline & & & & \multirow[t]{2}{*}{ RBP } & \multirow[t]{2}{*}{$\begin{array}{l}\text { Tubular } \\
\text { proteinuria }\end{array}$} & \multirow[t]{2}{*}{ GAA } & \multirow[t]{2}{*}{$\underset{\mathrm{pH}}{\text { Minimum }}$} & \multirow{2}{*}{$\begin{array}{c}\text { Maximum } \\
\text { osmolality } \\
\left(\mathrm{m} 0 \mathrm{Sm} / \mathrm{Kg} \cdot \mathrm{H}_{2} \mathrm{O}\right)\end{array}$} & \multirow{2}{*}{\multicolumn{2}{|c|}{$\begin{array}{l}\text { Culture } \\
(/ \mathrm{ml})\end{array}$}} & $C R$ & & FBS & $\mathrm{Ca}$ & $p$ \\
\hline & & & & & & & & & & & \multicolumn{5}{|c|}{$\square(\mathrm{mg} / \mathrm{dr})$} \\
\hline 1 & M & 66 & 46 & $(+)$ & $(+)$ & $(+)$ & 5.28 & 692 & negative & n.p. & 1.5 & 2.8 & 79 & 10.2 & 2.6 \\
\hline 2 & $M$ & 65 & 50 & & $(+)$ & $( \pm)$ & 5.24 & 804 & negative & n.p. & 1.1 & 4.3 & 78 & 9.2 & 3.1 \\
\hline 3 & M & 54 & 28 & $(-)$ & $(+)$ & $(+)$ & 5.17 & 864 & negative & n.p. & 1.1 & 4.4 & 76 & 9.3 & 3.3 \\
\hline 4 & $\mathrm{~F}$ & 74 & 62 & & $(+)$ & $(+)$ & 5.87 & 678 & negative & n.p. & 1.1 & 3.7 & 65 & 8.5 & 3.1 \\
\hline 5 & $\mathrm{~F}$ & 73 & 61 & $(+)$ & $(+)$ & $(+)$ & 5.76 & 887 & E.coli. $1 \times 10^{3}$ & n.p. & 1.2 & 2.9 & 74 & 9.3 & 2.5 \\
\hline 6 & $\mathrm{~F}$ & 67 & 61 & & $(+)$ & $(-)$ & 5.74 & 585 & negative & n.p. & 1.2 & 4.7 & 74 & 9.0 & 3.4 \\
\hline 7 & M & 69 & 69 & $(+)$ & $(+)$ & $(-)$ & 5.23 & 530 & & n.p. & 1.7 & 3.3 & 67 & 9.1 & 3.6 \\
\hline 8 & M & 67 & 67 & & $(-)$ & $(-)$ & 5.04 & 674 & & n.p. & 1.2 & 5.3 & 66 & 8.9 & 3.4 \\
\hline 9 & M & 64 & 46 & & $(-)$ & $(-)$ & 5.17 & 768 & & n.p. & 1.3 & 4.3 & 59 & 8.8 & 2.6 \\
\hline 10 & $\mathrm{~F}$ & 68 & 55 & & $(-)$ & $(-)$ & 5.04 & 701 & $\begin{array}{l}\text { St. epid. } \\
\text { 5. }\end{array}$ & massive & 1.3 & 4.3 & 90 & 8.3 & 3.6 \\
\hline 11 & $\mathrm{~F}$ & 60 & 47 & $(-)$ & $(-)$ & $(-)$ & 5.00 & 803 & E.cold. & n.p. & 0.9 & 3.7 & 66 & 8.7 & 4.4 \\
\hline 12 & $\mathrm{~F}$ & 58 & 47 & $(-)$ & $(-)$ & $(-)$ & 5.13 & 770 & $\begin{array}{l}\text { not identified } \\
5 \times 10^{4}\end{array}$ & n.p. & 0.8 & 4.7 & 63 & 9.5 & 4.4 \\
\hline 13 & $\mathrm{~F}$ & 53 & 37 & $(-)$ & $(-)$ & $(-)$ & 5.07 & 836 & $\begin{array}{l}\text { St.epid. } \\
8 \times 10^{3}\end{array}$ & n.p. & 0.7 & 4.9 & 86 & 9.8 & 4.1 \\
\hline
\end{tabular}

RBP: Retinol-binding protein. GAA: Generalized aminoaciduria. Minimum PH of urine: Values after $740 \mathrm{mEq}$ of ammonium chloride per day administered for three days. Maximum osmolality of urine: Values after overnight fasting. St:epid.: Staphylococcus epidermidis. CR: Creatinine. UA: Uric acid. FBS: Fasting blood sugar.

Normal range: Same as in Table 6.

Table 3. Laboratory findings on 13 hospitalized cases with concurrent proteinuria and glycosuria (II).

\begin{tabular}{|c|c|c|c|c|c|c|c|c|c|c|c|c|c|c|c|c|}
\hline \multirow[b]{2}{*}{ Case } & \multirow[b]{2}{*}{$L_{\text {(m) } / m i}^{C_{P A H}}$} & \multirow[b]{2}{*}{$\mathrm{Ccr}$} & \multirow[b]{2}{*}{ Cua } & \multirow[b]{2}{*}{$\mathrm{Cua} / \mathrm{Cor}$} & \multirow[b]{2}{*}{$\begin{array}{c}\text { PSP } \\
\text { test } \\
(\% \quad 15 \text { min })\end{array}$} & \multirow[b]{2}{*}{$\begin{array}{c}\mathrm{HCO}_{3}^{-} \\
\text {threshold } \\
(\mathrm{mEg} / \mathrm{l})\end{array}$} & \multirow[b]{2}{*}{$\%$ TRP } & \multirow[b]{2}{*}{ GTT } & \multicolumn{6}{|c|}{ Plasma } & \multirow[b]{2}{*}{$\begin{array}{l}\text { Cd in } \\
\text { urine } \\
(\mu \mathrm{g} / 1)\end{array}$} & \multirow[b]{2}{*}{$\begin{array}{l}\mathrm{Cd} \text { in } \\
\text { rice } \\
(\mu \mathrm{g} / \mathrm{g})\end{array}$} \\
\hline & & & & & & & & & $\mathrm{Ha}_{\mathrm{mE}}$ & K & $\begin{array}{c}\mathrm{Cl} \\
1\end{array}$ & $\mathrm{pH}$ & $\begin{array}{c}\mathrm{PcO}_{2} \\
(\mathrm{mmHg})\end{array}$ & $\begin{array}{c}\mathrm{CO}_{2-} \\
\text { content } \\
\text { (m mole } / 1)\end{array}$ & & \\
\hline 1 & 490 & 46 & 25 & 0.54 & 25 & 27 & 67 & normal & 145 & 3.9 & 706 & 7.406 & 38.0 & 24.5 & 45.0 & 0.57 \\
\hline 2 & & 66 & 17 & 0.26 & 29 & & 73 & normal & 140 & 4.7 & 106 & 7.400 & 39.0 & 24.7 & 19.0 & .0 .68 \\
\hline 3 & & 82 & 10 & 0.12 & 28 & & 77 & normal & 142 & 4.4 & 101 & 7.418 & 43.4 & 28.0 & & 0.22 \\
\hline 4 & 257 & 53 & 15 & 0.28 & 28 & 26 & 84 & normal & 143 & 3.2 & 107 & 7.362 & 42.7 & 25.3 & 3.4 & 0.42 \\
\hline 5 & 268 & 57 & 19 & 0.33 & 32 & 23 & 70 & norma 1 & 144 & 3.4 & 109 & 7.367 & 41.8 & 26.2 & 16.0 & 0.16 \\
\hline 6 & & 48 & 9 & 0.19 & 20 & 23 & 78 & norma] & 141 & 3.6 & 110 & 7.376 & 40.0 & 24.7 & 6.3 & 0.98 \\
\hline 7 & & 48 & 13 & 0.27 & 22 & 26 & 85 & norma 7 & 144 & 4.1 & 108 & 7.421 & 38.1 & 24.7 & 9.8 & 0.46 \\
\hline 8 & 325 & 67 & 7 & 0.10 & 11 & & 78 & norma 1 & 148 & 4.2 & 106 & 7.410 & 39.8 & 26.2 & 15.1 & 2.44 \\
\hline 9 & & 64 & 11 & 0.17 & 33 & & 85 & norma 7 & 142 & 3.8 & 107 & 7.427 & 38.9 & 25.5 & 6.4 & 0.64 \\
\hline 10 & 338 & 54 & 10 & 0.19 & 25 & 26 & 78 & normal & 142 & 4.2 & 103 & 7.380 & 44.8 & 26.7 & 10.5 & 1.27 \\
\hline 11 & 524 & 59 & 12 & 0.20 & 33 & 25 & 82 & norma 1 & 141 & 4.2 & 103 & 7.398 & 42.5 & 26.2 & 14.2 & 2.44 \\
\hline 12 & 460 & 102 & 10 & 0.10 & 33 & 24 & 90 & norma 1 & 144 & 3.7 & 107 & 7.390 & 40.3 & 24.5 & 13.1 & 0.68 \\
\hline 13 & 497 & 78 & 8 & 0.10 & 20 & 24 & 87 & norma] & 140 & 4.2 & 103 & 7.403 & 40.5 & 25.3 & 12.1 & 1.26 \\
\hline
\end{tabular}

$C_{\text {PAH }}$ :Para-aminohippuric acid clearance. Ccr:Creatinine clearance. Cua:Uric acid clearance. 1.48m ${ }^{2}:$ Body surface area of average Japanese adult. \%TRP:Renal tubular reabsorption of phsphate. GTT:Oral 100g glucose tolerance test.

Cd in urine:Cadmium concentration in morning urine. Cd in rice:Cadmium concentration in unpolished rice of their own production. Normal range: Same as in Table 6 . 
Table 4. Laboratory findings on 13 hospitalized cases with concurrent proteinuria and glycosuria (III).

\begin{tabular}{|c|c|c|c|c|c|c|c|c|c|c|c|c|c|c|c|c|}
\hline Case & $\begin{array}{l}\text { Plasma } \\
\text { protein } \\
(\mathrm{g} / \mathrm{d} l)\end{array}$ & $\begin{array}{l}\text { P } \\
\text { Alb. } \\
(\%)\end{array}$ & $\begin{array}{c}\alpha_{1} \\
(\%)\end{array}$ & $\begin{array}{c}\text { rotein } \\
\qquad \begin{array}{c}\alpha_{2} \\
(\%)\end{array}\end{array}$ & $\begin{array}{l}\text { fractio } \\
\qquad \begin{array}{c}\beta \\
(\%)\end{array}\end{array}$ & $\begin{array}{c}\gamma \\
(\%)\end{array}$ & $\begin{array}{l}\text { Colour } \\
\text { index }\end{array}$ & CCFT & $Z T T$ & $T T T$ & GOT & GPT & $\begin{array}{l}\text { Al. } \\
\text { P-ase } \\
(K . A)\end{array}$ & $\begin{array}{l}\text { T.Chol } \\
(\mathrm{mg} / \mathrm{dl})\end{array}$ & $\begin{array}{l}\text { Neutral } \\
\text { fat } \\
(\mathrm{mg} / \mathrm{dl})\end{array}$ & $\begin{array}{l}\text { Phosphol ipid } \\
\text { (mg/dl) }\end{array}$ \\
\hline 1 & 7.8 & 57.7 & 3.6 & 9.8 & 9.3 & 19.6 & 6 & $(-)$ & 12.9 & 6.4 & 41 & 29 & 9.2 & 159 & 154 & 158 \\
\hline 2 & 7.0 & 65.6 & 3.7 & 9.3 & 8.9 & 12.2 & 4 & $(-)$ & 4.0 & 1.2 & 23 & 14 & 5.4 & 205 & 86 & 223 \\
\hline 3 & 7.6 & 59.7 & 3.5 & 7.2 & 12.6 & 16.0 & 4 & $(-)$ & 6.2 & 5.1 & 19 & 7 & 5.8 & 215 & 78 & 200 \\
\hline 4 & 6.4 & 61.7 & 2.6 & 9.1 & 9.7 & 16.9 & 5 & $(-)$ & 7.9 & 2.5 & 13 & 2 & 15.4 & 130 & 62 & 149 \\
\hline 5 & 7.6 & 59.7 & 2.4 & 9.0 & 9.6 & 19.9 & 6 & $(-)$ & 12.6 & 6.2 & 25 & 20 & 10.8 & 208 & 80 & 195 \\
\hline 6 & 6.8 & 52.6 & 3.4 & 8.5 & 10.3 & 25.2 & 9 & $(+++)$ & 12.4 & 4.2 & 48 & 25 & 8.8 & 148 & 76 & 146 \\
\hline 7 & 6.7 & 55.5 & 4.6 & 10.4 & 9.8 & 19.7 & 6 & $(-)$ & 11.5 & 5.2 & 13 & 8 & 10.5 & 192 & 161 & 190 \\
\hline 8 & 6.7 & 58.3 & 3.1 & 10.3 & 10.9 & 15.9 & 3 & $(++)$ & 8.1 & 3.3 & 17 & 6 & 5.1 & 170 & 101 & 194 \\
\hline 9 & 6.5 & 62.5 & 2.5 & 8.6 & 7.4 & 19.0 & 6 & $(t+)$ & 8.4 & 2.9 & 14 & 7 & 5.6 & 216 & 73 & 179 \\
\hline 10 & 7.5 & 66.2 & 2.5 & 10.4 & 8.5 & 12.4 & 3 & $(+)$ & 6.4 & 1.3 & 9 & 7 & 11.3 & 227 & 180 & 234 \\
\hline 11 & 7.4 & 61.5 & 3.7 & 8.7 & 9.3 & 16.8 & 5 & $(-)$ & 10.8 & 2.2 & 8 & 8 & 14.3 & 158 & 130 & 157 \\
\hline 12 & 6.4 & 61.1 & 2.7 & 10.4 & 9.9 & 15.9 & 5 & $(-)$ & 5.2 & 1.4 & 15 & 14 & 9.8 & 208 & 159 & 200 \\
\hline 13 & 7.3 & 58.7 & 3.2 & 11.0 & 9.0 & 18.1 & 4 & & 8.1 & 1.5 & 13 & 9 & 8.5 & 187 & 102 & 204 \\
\hline
\end{tabular}

Plasma protein fraction: Analysed by cellulose acetate electrophoresis. Al.P-ase: Alkaline

phosphatase. T.Chol: Total cholesterol.

Normal range of the liver function tests: CCFT $(-)$, ZTT $<12, \operatorname{TTT}<4$, GOT $<40$, GPT $<35$

Alkaline phosphatase $<10$.

tubular dysfunctions.

5) Laboratory findings in 13 hospitalized cases with concurrent proteinuria and glycosuria (Table 2-5):

Renal function tests were carried out so far in 25 of the 33 cases with concurrent proteinuria and glycosuria. Thirteen of the 25 cases were hospitalized for two months in Tohoku University Hospital to receive detailed examinations. The results were all obtained in these cases under conditions without any treatments.

All the 13 cases had lived in Hosogoe, Kosaka town for over 28 years, with no blood relations to each other, and no abuse of drugs. There were no bedridden cases. All cases showed slight proteinuria, with a range of $20-100 \mathrm{mg} / \mathrm{dl}$ in 24-hour urine protein concentration.

In Fishberg's concentration test, only 5 of the 13 cases had a maximum urine osmotic pressure of over $800 \mathrm{mOsm} / \mathrm{kg} . \mathrm{H}_{2} \mathrm{O}$, the remaining 8 showing an evident reduction in the concentrating ability of urine.

In quantitative urine culture using midstream urine, no cases revealed bacteriuria.
In urine sediment, no abnormalities were found in all but one (Case 10).

In endogeneous creatinine clearance, most cases showed a low value around 60 $\mathrm{ml} / \mathrm{min}$.

Eight of the 13 cases had a high value over 0.19 in uric acid clearance per unit nephron (uric acid clearance/creatinine clearance). In PSP excretion test 4 showed less than $25 \%$ in 15 -minute value.

In $\mathrm{HCO}_{3}^{-}$-threshold, 4 cases had a low value of less than $24 \mathrm{mEq} / 1$.

In tubular reabsorption of phosphate ( $\%$ TRP), 7 cases had a low rate of $79 \%$ or less.

Fasting blood and sugar glucose tolerance test were normal in all 13 cases. From these findings glycosuria observed in these cases was diagnosed as renal glycosuria.

In arterial plasma $\mathrm{pH}$ and $\mathrm{CO}_{2}$-content checked in all 13 cases none showed metabolic acidosis.

Intraveneous pyelography performed in all 13 cases disclosed no abnormalities such as enlargement or deformities of the pelvicocalyceal systems, nor nephrocalcinosis. Case 
Table 5. Laboratory findings on 13 hospitalized cases with concurrent proteinuria and glycosuria (IV).

\begin{tabular}{|c|c|c|c|c|c|c|c|c|c|c|c|c|c|}
\hline Case & $\begin{array}{l}\mathrm{RBC} \\
\left(\times 10^{4} / \mathrm{mm}^{3}\right)\end{array}$ & $\begin{array}{l}\mathrm{Hb} \\
(\% \operatorname{Sah} 1 i)\end{array}$ & )$^{W B C}\left(/ / m^{3}\right)$ & $\begin{array}{l}\text { ESR } \\
(\mathrm{mm} / \mathrm{h})\end{array}$ & STS & RA & CRP & $\begin{array}{l}\text { ASLO } \\
\text { (Todd) }\end{array}$ & LEtest & B.P. & Fundi & ECG & Remarks \\
\hline 1 & 563 & 107 & 4200 & 3 & $(-)$ & $(-)$ & $(-)$ & 50 & $(-)$ & $120 / 80$ & KW-IIa & normal & Silicosis \\
\hline 2 & 447 & 65 & 4400 & 2 & $(-)$ & $(-)$ & $(-)$ & 12 & & $142 / 76$ & & $\begin{array}{l}\text { atrial } \\
\text { fibritiation }\end{array}$ & $\begin{array}{l}\text { atrial } \\
\text { fibrillation }\end{array}$ \\
\hline 3 & 370 & 85 & 5100 & 8 & $(-)$ & $(-)$ & $(-)$ & 12 & $(-)$ & $130 / 80$ & KW-IIb & LVH & \\
\hline 4 & 426 & 84 & 6600 & 18 & $(-)$ & $(+)$ & $(-)$ & 50 & $(-)$ & $130 / 80$ & normal & LVH & \\
\hline 5 & 443 & 80 & 4400 & 15 & $(-)$ & $(-)$ & $(-)$ & 12 & $(-)$ & $132 / 64$ & normal & normal & \\
\hline 6 & 443 & 82 & 3000 & 23 & $(-)$ & $( \pm)$ & $(-)$ & 50 & $(-)$ & $128 / 68$ & KW-IIa & LVH & $\begin{array}{l}\text { cirrhosis } \\
\text { of the liver }\end{array}$ \\
\hline 7 & 379 & 75 & 3700 & 17 & $(-)$ & $(+)$ & +2 & 50 & $(-)$ & $170 / 90$ & KW-III & LVH & $\begin{array}{l}\text { Rheumatoid } \\
\text { arthritis }\end{array}$ \\
\hline 8 & 376 & 73 & 4600 & 28 & $(-)$ & $(-)$ & $(-)$ & 50 & & $140 / 85$ & norma $]$ & LVH & $\begin{array}{l}\text { Essential } \\
\text { hypertension }\end{array}$ \\
\hline 9 & 456 & 88 & 6700 & 3 & $(-)$ & $(-)$ & $(-)$ & 12 & $(-)$ & $120 / 80$ & normal & normal & \\
\hline 10 & 415 & 85 & 3800 & 15 & $(+)$ & $(+)$ & $(-)$ & 50 & $(-)$ & $130 / 70$ & normal & normal & \\
\hline 11 & 389 & 83 & 3000 & 10 & $(-)$ & $(-)$ & $(-)$ & 166 & $(-)$ & $134 / 70$ & KW-IIa & normal & \\
\hline 12 & 418 & 85 & 7200 & 17 & $(-)$ & $(-)$ & $(-)$ & 50 & $(-)$ & $136 / 78$ & KW-I & normal & \\
\hline 13 & 394 & 80 & 9200 & 30 & $(-)$ & $(+)$ & +1 & 50 & $(-)$ & $128 / 80$ & normal & normal & $\begin{array}{l}\text { Reumatoid } \\
\text { arthritis }\end{array}$ \\
\hline
\end{tabular}

RBC: Red cell count. Hb: Hemoglobin. WBC: White cell count. ESR: Erythrocyte sedimentation rate.

STS: Serological test of syphilis. RA: Hyland RA test. ASLO: Antistreptolysin-0 titer.

LE test: Hyland LE test. B.P.: Blood pressure. KW: Keith-Wagener classification of Fundi.

ECG: Electrocardiogram. LVH: Left ventricular hypertrophy.

1 showed bilateral nephrolithiasis. Case 6 had undergone right nephrectomy for nephrolithiasis 20 years before.

On the basis of our diagnostic criteria, 6 (Case 1-6) of the 13 cases were diagnosed as having multiple proximal tubular dysfunctions.

Serum protein concentration was normal in all cases. In serum protein fractions no cases were abnormal except Case 6 with a high value of $25.2 \%$ in gamma-globulin fraction.

In liver function tests, dysfunction was evident in one (Case 6), slight in 6 other cases, but there were no abnormalities in the remaining 6 cases. Alkaline phosphatase was slightly high in 5 , but normal in the other 8 cases.

In peripheral blood analysis, many of the cases were normal though some had slight anemia.

One case (Case 7) had a high blood pressure, which was diagnosed as essential hypertension as the results of detailed examinations. The other 12 cases had no hypertension.

Many of the cases with multiple proximal tubular dysfunctions tended to show hepatic dysfunctions as well. But there were no particular correlations between the results of other laboratory data and the severity of tubular dysfunction.

The results of detailed examinations revealed silicosis in Case 1, atrial fibrillation in Case 2, cirrhosis of the liver in Case 6, essential hypertension and chronic rheumatoid arthritis in Case 7, and chronic rheumatoid arthritis in Case 13. There were no particular disorders in the other 8 cases.

6) Laboratory findings in 12 non-hospitalized cases with concurrent proteinuria and glycosuria (Table 6):

In these cases, the fasting 2-hour urine (6.00-8.00 a. m.) and blood (at 7.00 a. m.) were examined to determine endogeneous crea- 
Table 6. Laboratory findings on 12 non-hospitalized cases with concurrent proteinuria and glycosuria.

\begin{tabular}{|c|c|c|c|c|c|c|c|c|c|c|c|c|c|c|c|c|}
\hline \multirow[t]{2}{*}{ Case } & \multirow[t]{2}{*}{ Sex } & \multirow[t]{2}{*}{ Age } & \multirow{2}{*}{$\begin{array}{l}\text { Years of } \\
\text { residence }\end{array}$} & \multirow{2}{*}{\multicolumn{2}{|c|}{$\begin{array}{l}\text { Ccr cua } \\
{\left[\begin{array}{c}(\mathrm{m} 1 / \mathrm{min} / \\
1.48 \mathrm{~m})\end{array}\right.}\end{array}$}} & \multirow[t]{2}{*}{$\mathrm{Cua} / \mathrm{Ccr}$} & \multirow[t]{2}{*}{$\%$ TRP } & \multicolumn{3}{|c|}{ Urine } & \multicolumn{4}{|c|}{ Plasma } & \multirow{2}{*}{$\begin{array}{l}\text { Cd in } \\
\text { urine } \\
(\mu \mathrm{g} / 1)\end{array}$} & \multirow{2}{*}{$\begin{array}{l}\text { Cd in } \\
\text { rice } \\
(\mu g / g)\end{array}$} \\
\hline & & & & & & & & RBP & $\begin{array}{l}\text { Tubular } \\
\text { roteinuria }\end{array}$ & GAA & $\stackrel{C R}{L}$ & $\begin{array}{r}\text { UA } \\
(\mathrm{mg} / \mathrm{d}\end{array}$ & FBS & $\stackrel{p}{2}$ & & \\
\hline 14 & M & 83 & 63 & 32 & 6 & 0.19 & 55 & $(+)$ & $(+)$ & $(+)$ & 1.5 & 4.9 & 80 & 2.1 & 17.3 & \\
\hline 15 & M & 36 & 36 & 84 & 23 & 0.27 & 72 & $(+)$ & & $\left(\begin{array}{l}+ \\
-\end{array}\right)$ & 1.0 & 2.6 & 75 & 2.8 & & 0.57 \\
\hline 16 & $\mathrm{~F}$ & 80 & 80 & 28 & 10 & 0.36 & 47 & $(+)$ & $(+)$ & $(+)$ & 2.1 & 2.9 & 76 & 2.0 & 15.3 & 0.50 \\
\hline 17 & $\mathrm{~F}$ & 73 & 57 & 22 & 8 & 0.36 & 78 & $(+)$ & $(+)$ & $(+)$ & 1.7 & 3.0 & 94 & 2.7 & 12.6 & 3.86 \\
\hline 18 & M & 56 & 56 & 42 & 4 & 0.11 & 89 & $(-)$ & & $(-)$ & 1.1 & 5.0 & 55 & 2.7 & 11.3 & \\
\hline 19 & M & 47 & 47 & 81 & 17 & 0.20 & 86 & $(-)$ & & $(-)$ & 0.9 & 3.4 & 87 & 4.0 & & \\
\hline 20 & M & 43 & 43 & 103 & & & 89 & & $(-)$ & $(-)$ & 1.0 & & & 3.0 & & 0.67 \\
\hline 21 & M & 42 & 42 & 80 & & & 86 & & $(-)$ & $(-)$ & 1.0 & & & 3.1 & & 0.64 \\
\hline 22 & M & 35 & 35 & 73 & 9 & 0.12 & 86 & $(-)$ & & $(-)$ & 1.0 & 3.4 & 68 & 4.0 & & \\
\hline 23 & M & 35 & 35 & 40 & 5 & 0.12 & 81 & $(-)$ & & $(-)$ & 1.2 & 5.4 & 77 & 3.0 & & \\
\hline 24 & $\mathrm{~F}$ & 61 & 61 & 146 & 47 & 0.32 & 82 & $(-)$ & & $(-)$ & 0.8 & 2.1 & 75 & 2.8 & 11.7 & \\
\hline 25 & $\mathrm{~F}$ & 59 & 43 & 68 & 19 & 0.28 & 85 & $(-)$ & $(\stackrel{+}{)})$ & $(\stackrel{+}{-})$ & 1.1 & 3.3 & 66 & 3.6 & & \\
\hline
\end{tabular}

Normal range: Cua/Ccr 0.05-0.15. \%TRP 83-95. Plasma uric acid 3.8-7.5mg/dl (adult males), 3.0-5.5mg/dl (adult females), respectively. Plasma phosphate $2.8-4.3 \mathrm{mg} / \mathrm{d} 1$.

Abbreviations: Same as in Table 2 and 3.

tinine clearance, phosphate clearance, uric acid clearance, blood sugar and plasma electrolytes.

Glycosuria observed in all cases was confirmed as renal glycosuria because their fasting blood sugar remained in a normal range.

A high value of plasma creatinine and a low value of endogeneous creatinine clearance were found in 2 cases.

In uric acid clearance per unit nephron (uric acid clearance/creatinine clearance), 7 cases had a marked high value of over 0.19 .

Four cases had obvious hypophosphatemia of less than $2.7 \mathrm{md} / \mathrm{dl}$, and a decreased $\%$ TRP of less than 79 was found in 4 cases.

Tubular proteinuria or urinary retinolbinding protein was positive in 4 cases. All these 4 also showed generalized aminoaciduria or increased excretion of urinary aminoacids.

These 12 individuals living in Hosogoe for over 36 years had no particular habitual drugs. Except for one case (Case 17) undergoing traction therapy for lumbago in the Kosaka hospital, there were no bedridden cases.
According to our diagnostic criteria, 4 (Case 14-17) of the 12 cases were diagnosed as having multiple proximal tubular dysfunctions.

No cases other than Case 15, the son of Case 1, had blood ties with each other among the total 25 cases.

7) Bone X-ray findings:

Bone X-ray examinations were performed in all 13 hospitalized and 5 of the 12 nonhospitalized cases (Case 14, 16, 17, 20 and 24), totaling 18.

All but Case 20 showed diffuse decreased bone density, the observed changes were severer in females than in males. Spine formation of vertebral bodies was found in some males and fish vertebrae or vertebral flattening in some female cases. In the left pubic bone of Case 1, there was an indication suspected as Looser's line. No such sign was recognized in the other 17 cases. Bone biopsies were not carried out in these cases.

8) Urinary cadmium levels in cases with concurrent proteinuria and glycosuria, and cadmium concentrations in unpolished rice of their own production (Table 3,6):

The result of urinary cadmium levels 
were provided by courtesy of the Akita Prefectural Government in 1973. Cadmium concentration levels in household unpolished rice were used of those cross-checked by Dr. Shin Homma (Tokyo University of Agriculture and Technology) and the Akita Prefectural Government in the rice produced in 1970-1975.

Urinary cadmium levels checked in 8 cases of multiple proximal tubular dysfunctions were abnormally high in 6 of them ranging $12.6-45.0 \mu \mathrm{g} / \mathrm{l}$. Seven of 9 cases with the same dysfunctions had high levels of cadmium concentration ranging $0.42-3.86 \mu \mathrm{g} / \mathrm{g}$ wet weight in their household unpolished rice. In other words, as many as 9 of 10 cases diagnosed as having multiple proximal tubular dysfunctions had an abnormally high value in urinary cadmium level or in cadmium concentration in the rice of their own production, or both.

Abnormally high values of cadmium concentration in urine and the household unpolished rice were observed as well in most of the cases with concurrent protenuria and glycosuria showing no multiple proximal tubular dysfunctions.

\section{DISCUSSION}

Regarding the cause of so-called "ItaiItai disease" in the Jinzu river basin, Toyama prefecture, the Ministry of Health and Welfare issued an official statement in 1968 as: "So-called Itai-Itai disease is first insinuated by chronic cadmium poisoning which leads to renal dysfunction followed by osteomalacia. And pregnancy, breast lactation, hormonal disturbances, aging, or calcium deficiency may further participate in developing this Itai-Itai disease".

The Ministry of Health and Welfare and the Environmental Agency, establishing "Method of health examinations for people in areas of environmental cadmium pollution (1969)", have been carrying out health examinations for people in cadmium-polluted areas in Prefectures of Miyagi, Nagasaki, Fukushima, etc. But so far so-called "ItaiItai disease" has not been identified in any people of the cadmium-polluted areas except for the Jinzu river basin.

If health hazards induced by environmental cadmium pollution are to be decided by the identification of so-called "Itai-Itai disease", it may be affirmed that there are no cadmium-induced health hazards in any cadmium-polluted areas where so-called "Itai-Itai disease" has not been recognized.

The existing method of health examinations has mostly followed the method for detection of so-called "Itai-Itai disease" used in Jinzu river basin. This method, emphasizing the detection of bone involvements, seems to have paid little attention to the detection of renal lesions, especially tubular dysfunctions.

This is quite evident from the fact that examinations of the kidney in this method only covered qualitative urine test, measurement of urine proteins, electrophoretic analysis of urine proteins, and PSP excretion test.

We believe that health examinations laying emphasis on bone involvements without full attention to renal lesions, are difficult to identify early and exact changes of health hazards induced by the environmental cadmium pollution.

Rationale are as follows:

1. Renal lesions in chronic occupational cadmium poisoning are multiple proximal tubular malfunctions, developing low molecular weight proteinuria or tubular proteinuria, renal glycosuria, generalized aminoaciduria, decreased $\% \mathrm{TRP}$, a high value of uric acid clearance, and renal tubular $\operatorname{acidosis}^{11-15)}$.

Osteomalacia frequently associated with Fanconi sydrome is well known to be mainly caused by phosphate leak and renal tubular $\operatorname{acidosis}^{16)}$.

In view of renal lesions from chronic cadmium poisoning being essentially multiple proximal tubular malfunctions, there is a possibility that cases with this cadmium poisoning develop osteomalacia through renal lesions. Reports of Lafitte, Gervais and Adams citing osteomalacia in cadmiumworkers well suggest the above possibility ${ }^{15,17,18)}$. 
It may be justifiable to relate osteomalacia in the residents of cadmium-polluted areas to health hazards induced by the environmental cadmium pollution. Even in this case, however, osteomalacia patients being considered to represent cases of highly advanced proximal tubular malfunctions, it is reasonable to believe that there would be many more cases with less-advanced proximal tubular malfunctions short of developing osteomalacia.

2. In discussing osteomalacia in so-called "Itai-Itai disease", there is an argument suspecting cadmium-induced enteropathy as its primary cause, and renal tubular malfunctions rather as a secondary factor ${ }^{2,19}$. Even on this standpoint, coexistence of cadmium-induced bone involvements and renal lesions is not fully denied.

3. Among main lesions associated with chronic occupational cadmium poisoning, although lung emphysema and anosmia have been cited aside from renal lesions, it is generally believed that proximal tubular malfunctions originating from low molecular weight proteinuria or renal glycosuria is the highest in incidence ${ }^{11,14,15,20)}$.

Both lung emphysema and anosmia secondary to the inhalation of cadmium dust $^{11,14,15,20)}$ are considered to occur less frequently in cases with chronic cadmium poisoning caused by mass intakes of cadmium via food.

4. In experimental animals given cadmium, the resultant development of osteomalacia has been indefinite, but there is no doubt about the development of proteinuria, glycosuria and aminoaciduria representing proximal tubular malfunctions ${ }^{11,20,21)}$.

On these grounds, we prefer the development of proximal tubular malfunctions as the most appropriate indication of health hazards induced by environmental cadmium pollution. In other words, when "the incidence of concurrent proteinuria and glycosuria is significantly higher in both sexes in a cadmium-polluted area than in control areas, and there are residents with multiple proximal tubular dysfunctions difficult to be traced to any other causes than chronic cadmium poisoning", it seems conceivable to believe that health hazards exist with environmental cadmium pollution.

In our urine tests we found concurrent proteinuria and glycosuria in 13-22\% of the Hosogoe residents against $2.5 \%$ in controls.

In contrast with the incidence of concurrent proteinuria and glycosuria known as around 2-5\% for people in non-polluted areas $^{22)}$, the figures for the Hosogoe residents were strikingly high in both sexes.

Concurrent proteinuria and glycosuria was detected in 33 of 137 residents who had undergone urine tests. The 33 residents were from middle to old age living in Hosogoe for long years. Renal function tests performed in 25 of the 33 cases revealed multiple proximal tubular dysfunctions in 10 of them.

There are many diseases known as causing multiple proximal tubular dysfunctions. In Table 7 we show Morris' classification with some modification ${ }^{23)}$.

Causal diseases were traced for multiple proximal tubular dysfunctions identified in 10 cases out of the 137 residents.

In 6 (Case 1-6) of these 10 cases, detailed examinations carried out for two months in Tohoku University Hospital denied any idiopathic, hereditary or aquired diseases other than chronic heavy metals poisoning.

Although in non-hospitalized 4 cases (Case 14-17), examinations were not as thorough as those in hospitalized 6 cases, findings in personal inquiries, physical examinations, analyses of serum and urine proteins, and others, also denied other causes than chronic heavy metals poisoning.

The Hosogoe area of Kosaka town, adjacent to a leading copper refinery in Japan, has been polluted by cadmium for industrial smokestacks since the $1870 \mathrm{~s}$, with frequent hard hits on agricultural products, livestock and trees. Examinations performed by Dr. Shin Homma and the Akita Prefectural Government repeatedly disclosed high concentrations of cadmium in the area's soil, rice and vegetables.

It is therefore conceivable that Hosogoe residents have long been forced to take in 
Table 7. Causal diseases of multiple tubular dysfunctions.

I. Idiopathic
sporadic
familial
II. A part of hereditary diseases
Cystinosis
Galactosemia
Tyrosinemia
Wilson's disease
Giycogen storage disease
Lowe's syndrome
III. Secondary to aquired diseases
Multiple myeloma
Light chain cisease
Nephrotic syndrome
Recovery stage of acute tubular necrosis
Sjögren's syndrome
Vitamin-D deficiency
Vitamin-D intoxication
Malabsorption syndrome
Primary hyperparathyroidism
Kidney transplantation
Heavy metals poisoning
Drugs
Experimental
Maleic acid
Malonic acid
IV.

abnormally large amounts of cadmium mainly through food.

Kojima in 1974 conducted extensive studies for 156 people in cadmium-polluted communities of Kosaka town including Hosogoe, ages ranging 50-69 years and for 93 people of the same age group in noncadmium-polluted Ikawa town, Akita prefecture $^{24)}$. The results revealed that 58 of the 156 Kosaka residents had a high concentration of urinary cadmium over $10 \mu \mathrm{g} / \mathrm{l}$, while none of the 93 Ikawa residents showed such a high level. The average urinary cadmium concentration was $8.0 \mu \mathrm{g} / \mathrm{l}$ for the Kosaka residents, but only $2.4 \mu \mathrm{g} / 1$ for the Ikawa residents, showing a statistically significant difference between the two. In cadmium levels in feces, a mean of $50.5 \mu \mathrm{g} /$ day was shown in 64 Ikawa people, includ- ing none with over $150 \mu \mathrm{g} /$ day, in contrast with a mean of $176.8 \mu \mathrm{g} /$ day for 118 Kosaka people, with over $150 \mu \mathrm{g} /$ day in $50 \%$ of them and over $300 \mu \mathrm{g} /$ day in $16 \%$.

The mean cadmium intake by people of non-cadmium polluted areas in Japan is assessed as $60 \mu \mathrm{g} / \mathrm{day}^{2}$.

Intestinal absorption of cadmium is less than $10 \%$ of its intake, so the daily excretion of cadmium in feces is considered almost equivalent to the daily intake of cadmium ${ }^{25)}$.

The daily intake of cadmium in Ikawa people estimated from their daily excretion of cadmium in feces agrees very well with the figure shown by the Ministry of Health and Welfare.

The fact that the residents of cadmiumpolluted Kosaka town had a mean daily cadmium excretion in feces over three times that for the residents of control area clearly shows that Kosaka people are still under serious exposure to cadmium.

As shown in Table 3 and 6, abnormally high concentrations of cadmium were detected in urine and household rice in 9 of 10 cases with multiple proximal tubular dysfunctions, and in 20 of 21 cases with concurrent proteinuria and glycosuria. These cases were all people living in Hosogoe from 28 to 80 years. It is quite sure that they have had a high daily intake of cadmium for long years via food.

Renal lesions and abnormal exposure to cadmium identified in many of the Hosogoe residents agree completely with those in chronic occupational cadmium poisoning and experimental cadmium poisoning ${ }^{11,14,15,20,21)}$.

From these findings we concluded that proximal tubular malfunctions identified in the Hosogoe residents were due to chronic cadmium poisoning induced by the environmental cadmium pollution.

According to our belief in the importance of renal function tests in health examinations for people in cadmium-polluted areas, we diagnosed cadmium-induced proximal tubular malfunctions for the first time in the world.

In 1974, the Environmental Agency set about health examinations for residents in 
cadmium-polluted areas in three prefectures of Akita ${ }^{24)}$, Yamagata ${ }^{26)}$, and $\mathrm{Hyogo}^{27)}$ using a new method which has taken in renal function tests paying regard to our method and results mentioned above.

The results are quite similar to ours on the Hosogoe area. The incidence of proximal tubular malfunctions was significantly higher in people of cadmium-polluted area than in controls.

It is believed necessary that in other cadmium-polluted areas as well health examinations should similarly be conducted to identify health hazards with environmental cadmium pollution.

\section{REFERENCES}

1) Itai-Itai Disease Research Committee supported by Ministry of Education (1963-1965), and Itai-Itai Disease Study Group supported by Ministry of Health and Welfare (1963): A Report of Studies on "So-called Itai-Itai Disease", 1967 (In Japanese).

2) Friberg L, et al: Cadmium in the Environment, 2nd ed, CRG Press, Gleveland, Ohio, p. 137, 1974.

3) Saito $\mathrm{H}$, et al: Polyacrylamide gel electrophoretic and immunochemical studies on urinary protein in Sjögren's syndrom, with special reference to tubular proteinuria. Tohoku J Exp Med 101: 205, 1970.

4) Gocke DJ, Howe G: Rapid detection of australia antigen by counter immunoelectrophoresis. J Immunol 104 : 1031, 1970.

5) Brenner DJ, Niederwieser A: DünnschichtChromatographie von Aminosäuren. Experientia 16:378, 1960.

6) Brod J, Sirota JH: The renal clearance of endogeneous 'creatinine' in man. J Clin Invest $27: 645,1948$.

7) Fiske CH, SubbaRow Y: The colorimetric determination of Phosphorus. J Biol Chem 66: 375, 1925.

8) Feichtmeir TV, Wrenn HT: Direct determination of uric acid using uricase. Amer J Clin Path 25 : 833, 1955.

9) Shioji R, et al: Oral administration of sodium bicarbonate to patients with renal tubular acidosis. Tohoku J Exp Med 114: 1, 1974.

10) Shioji R, et al: Renal excretion of ammonium in renal tubular acidosis. Tohoku J Exp Med 114: 301, 1974.
11) Friberg L: Health hazards in the manufacture of alkaline accumulators with special reference to chronic cadmium poisoning. Acta Med Scand Suppl 240: 7, 1950.

12) Piscator $M$ : Proteinuria in chronic cadmium poisoning. III. Electrophoretic and immunochemical studies on urinary proteins from cadmium workers, with special reference to the excrection of low molecular weight proteins. Arch Environ Health, 12 : 335, 1966.

13) Glarkson TW, Kench JE: Urinary excretion of amino acids by men absorbing heavy metals. Biochem J 62: 361, 1956.

14) Kazantzis G, et al: Renal tubular malfunction and pulmonary emphysema in cadmium pigment workers. Quart J Med 32 : 165, 1963.

15) Adams RG, et al: The development of cadmium-induced proteinuria, impaired renal function, and osteomalacia in alkaline battery workers. Quart J Med 38: 425, 1969.

16) Yendt ER: Disorders of calcium, phosphorus, and magnesium metabolism, Clinical Disorders of Fluid and Electrolyte Metabolism (Maxwell MH, Kleeman CR, eds), 2nd ed, McGraw-Hill Book Company, New York, p. 459, 1972.

17) Lafitte A, Gross A: Les lésions osseuses de l'intoxication chronique par le cadmium. Presse Méd 50: 399, 1942.

18) Gervais J, Delpech P: L'intoxication cadmique (I). Arch Mal Prof 24: 803, 1963.

19) Murata I, et al: Itai-Itai disease. Saishin Igaku 26: 1954, 1971 (In Japanese).

20) Friberg L: Chronic cadmium poisoning. Arch Industr Health 20: 401, 1959.

21) Friberg L, et al: Cadmium in the Environment, 2nd ed, CRG Press, Cleveland, Ohio, p. 107, 1974.

22) The Section for Hygien of the Hyogo Prefecture Authorities: Results of Studies on the Health Effects of Cadmium on the Population in the Vicinity of the Mine in Ikuno (II), 1973 (In Japanese).

23) Morris RC: Renal tubular acidosis. Mechanism, classification and implications. New Engl J Med 281: 1405, 1969.

24) Kojima S, et al: Results of studies on the health effects of cadmium on the population in Kosaka town, Akita prefecture. Kankyo Hoken Report (No. 36), Japanese Association of Public Health, Tokyo, p. 114, 1976 (In Japanese).

25) Friberg L, et al: Cadmium in the Environment, 2nd ed, CRG Press, Cleveland, Ohio,

Jap J Med Vol 16, No 1 (January 1977) 
Cd-Induced Proximal Tubular Dysfunctions

p. 23,1974 •

26) The Section for Hygien of the Yamagata Prefecture Authorities: Results of the community health survey with reference to cadmium pollution in the Yoshino basin. Kankyo Hoken Report (No. 36), Japanese Association of Public Health, Tokyo, p. 109, 1976
(In Japanese).

27) Watanabe $\mathrm{H}$, et al: An epidemiological study of renal function on the population of cadmium-polluted area. Kankyo Hoken Report (No. 36), Japanese Association of Public Health, Tokyo, p. 105, 1976 (In Japanese). 